\title{
Developing Reflective Practitioners in Zimbabwe Teachers' Colleges
}

\author{
John Mpofu
}

\begin{abstract}
Scholars have advocated the importance of developing reflective teaching skills in teachers so as to produce critical thinking pupils from our schools. This study examined how pre-service teachers and the course instructor perceived reflective thinking at the start of a required literacy course in a pre-service teacher education program. Teacher educators in Zimbabwe need to consider carefully the impact of the work they do in training and developing critical thinkers in the education of the country. The intention of teaching is to bring about learning. In what way does teaching lead to the concept of learning? How does a teacher trainer develop critical thinking skills in a student teacher so that he/she can in turn develop these skills in the pupils?This study examined how student teachers in pre-service Teachers' colleges are taught, the structure of the course and the manner in which the practical teaching practice is organized. The study examined how the teacher educator contributed to the development of reflective thinking throughout the course and the study looked at how preservice teachers applied ideas learned through reflection at school. Data collection included individual interviews, focus group discussions, observations of the visual data workshop with students, and analysis of written assignments. Visits to the schools where student teachers practiced were also done.The data was collected over the period of two semesters using a purposeful sample of 60 students and 20teacher educators. The findings included the following (a) the mentors who are experienced teachers provide technical assistance to the student teachers. (b) The mentor can also provide personal support for the student teacher. (c) The mentor can also provide support for curriculum development. (d) Written assignments and dialogue taken from the visual data analysis workshop indicated pre-service teacher characteristics that are consistent with characteristics of reflective thinkers. This study may have implications for curricular design and implementation in future pre-service education courses. The visual data project provided a context within which the participants acted, allowing the researcher to understand what assignments, activities, and experiences demonstrated characteristics consistent with those of reflective thinkers.
\end{abstract}

\section{Introduction}

Zimbabwe is a country with a population of approximately 12973808 million people and gained independence in 1980 (ZimStat 2012). Since independence there has been a phenomenal growth in the educational sector. In 1979 there were 2401 primary schools with an enrolment of 819586 pupils. (Chivore 1986) On the other hand in the secondary sector in 1979there were 177 secondary schools with an enrolment of 66215 pupils.By 1984, 1291 secondary schools with an enrolment of 422845 pupils (Chivore 1986). (Chivore1986)suggests that the phenomenal expansion was aimed at meeting the educational aspirations of mainly the African people. The sudden expansion especially the secondary sector led to teacher shortage. According to the Morrison report (1988:5) "the training colleges understandably are under pressure to keep pace with incessant demand for more teachers, but it has been impossible to match the increase in the Intake over the years since independence with the corresponding increases in staff establishment and resources." In order to satisfy the large demand for teachers, the government introduced a new Secondary teacher training program.

\section{Post "A" Level two year course structure program in two colleges}

\begin{tabular}{|l|l|}
\hline Year 1 & Study two main subjects professional foundations, curriculum development \\
\hline Year 2 term 1 & Teaching practice for 13 weeks \\
\hline Year 2 terms 3 and 4 & Study theory and main subjects at college and write final examination. \\
\hline
\end{tabular}

The introduction of the "A"level teacher training program led to the rise of student teacher population between 1979 and 1992. (Morrison 1988) argued that in 1979 the college had 125 student teachers but by 1992 there were 1053 student teachers. One challenge that the Teachers' college faced was the relocation of experienced trainers from the colleges. The recruitment of experienced teachers without any training in teacher education is still common in Zimbabwean Teacher' Colleges. It is against such a background that this study sought to investigate the effectiveness of the Zimbabwean teacher education program with specific reference to the development of reflective teachers.Rudduck (1992:163) argues that it is the responsibility of teacher educators to help student teachers do three things namely develop a commitment to understanding of the world of the 
classroom. They need to acquire some basic principles of research that will allow them to feed their understanding. They also need to develop some constructive experience of what reflective research will yield when applied to the everyday problems and dilemmas of teaching and learning. Wallace (1991) supports Ruddock's view (1992) by stating that skilled professionals do reflect on their professional performance particularly when it goes well or badly. Barnes, Britton and Torbe (1990:8) suggested that "teaching is a highly skilled activity that requires of the teacher an immediate response to events as they develop. The teacher must attend not only to the long goals but also to the needs of pupils.

\section{Literature Review}

"Since 1975 the perception of a teacher as a decision maker has been replaced by the perception of the teacher as a reflective professional who constructs meaning" (Wubbels and Korthagen 1990:31) These scholars argue that reflection refers to a process where a teacher is engaged in structuring his/ her perception of a situation, actions or learning or when he/she is engaged in altering or adjusting these structures so as to maximize the learning of the pupils. If the teachers regard what they do as a series of partly explicit hypotheses to be tested, they are likely to become much more consciously aware of the principles and priorities upon which their teaching is based.

Van Manen (1977) stated that there are three levels of developing reflective skills. The first level refers to preparing the student teachers with the technical skills of selecting from among alternative teaching techniques for any classroom interaction. He argues that reflective teachers need to develop both attitudes and skills required for thinking through and responding to the purpose and consequences of their actions in the classroom. Zeichner (1981) and Buchanan (1983) believed that the way teaching practice is organized in the initial teacher training program should develop the reflective skills in the students. The student teachers need to be given the chance to look back at their teaching and learning process as a means of analyzing its effectiveness. It is important that the teacher educator creates the conditions that will be conducive for the student teacher to reconstruct and reflect on his /her practice. Schon(1983) presents the argument that student teachers should discover that their existing frame for understanding what happens in their classes is only of several possible ones, and this realization can be achieved if teachers reflect critically upon what they do and its results.

\section{1reflecting on the feelings of the teacher}

Richert (1992) argues that student teachers should be taught the skills of responding to their teaching. They should be given time to reflect alone on what they think about the lesson they taught. The teacher might reflect on their own worth as a teacher's the frustrations they felt about the pupils' responses and the uncertainties they have about teaching. Richert (1992:177) concludes by saying "as student teachers talk to themselves about their teaching, they respond to the perplexities of teaching in a personal way by questioning themselves and pondering their teaching actions and reactions." When a student teacher is taught skill of looking back and analyzing his/her teaching, there is a broad range of topics that they will reflect on.

\subsection{Reflecting on the content}

The student teacher can be encouraged to reflecton the contenthe/she taught throughout the week by reflecting on the lesson plans schemes mark lists and methodology used in different lessons. The student teacher can be encouraged to think of alternativeways of teaching the content. (Richert1992) argues that initially when student teachers are asked to evaluate their lesson plans and schemes, they do so as a means of satisfying the requirements of the school or college. The motive is not to reconstructthe past in order to understand it more fully and learn from these experiences. It is therefore important for the teacher educator to develop the skill of reflection on past performance and make a record of the means of improvement in the future.

\subsection{Reflecting on teaching techniques}

The student teachers can reflect on how he/she can teach more effectively, how to question effectively, how to give instructions, how to organize materials and how to develop the differentskills in any subject. Freeman (1990:109) argues that the teacher educator provides alternatives which the student teacher can accept or reject. "The purpose of the intervention is to develop the student teachers' awareness of the choices involved in deciding whatand how to teach and that helps the student more importantly, to develop the ability to establish and articulate the criteria that inform that decision." What is important in the process is not only the choices which the student teacher has to make but the reason that helps the student teacher to make that choice. The teacher educator should avoid supplying solutions to the student teacher's classroom problems. Freeman (1990:111 concludes by suggesting that " such a stance is out of place in addressing the student teachers' reasoning process and can become counter- productive by creating a dependency. 


\subsection{Integrating theory and practice}

Verloop (1989:10) argues that "Educational theory has a well-established place in teacher education programs." In Zimbabwe, the theory of education course comprises curriculum development and education foundations. Although I have argued elsewhere that teaching is a profession, Cruickshank (1985) is quoted by Verloop(1989:10) as having said that "the most serious obstacle preventing teaching from having true professional status is a lack regarding of consensus among educators regarding what constitutes the requisite body of knowledge and skills for effective teaching." The criticism of teacher educators for failing to effectively use educational literature and theories in developing and training teachers as professionals was made by Sanders and McPeck (1976).

Sanders and McPeck (1976) argued that student teachers use the terms "theory" and" practice" as opposing concepts. Verloop (1989) argue that it has been known that some teacher educators will teach some elements of educational theory that has a direct relationship to the teacher's work in the classroom. He argues that such an approach might restrict oneself to a number of how to do ruleswithout fostering an understanding of the teaching learning process. Verloop (1989:12) Quotes McPhie(1978) and Stones (1983) warn against providing prospective teachers with tips that might work in some conditions but, without knowledge of the fundamental principles and basic theoretical concepts, would be useless or even harmful in other situations." Verloop (1989) observes that given that student teachers do not value theory, it is important for the teacher education program to be structured in an integrated way so that theory is integrated with practice.

Stones (1987) outlined that in many educational programs, educational theory is presented in an extremely theoretical manner with little reference to its practical application. What the teacher educator needs to do is integrate teacher training and teacher development as the principles of education process. (Freeman 1989: 33) argues that "awareness provides the dynamics that scan the field to be known and is therefore both a condition and a means of knowing." He explains that the development of awareness may be immediate or it may take a long time, until someone triggers it.The assumption that Freeman (1989) makes is that when a student teacher gets to a college he/she brings with him/her previous experience of the way he/she was taught. Freeman (1989:34) quotes Gattegno(1987) who stated that "Awareness is needed to bring back what is known and work on it again to change it, make it more conscious, more precise, more useful and connected with other knowledge.

Freeman (1989) suggests that an effective teacher education program needs to be interactive involving the teacher educator and the trainee." The two individuals, the teacher and the collaborator, engage in a process, the purpose of which is to generate some form of change in the teacher" (Freeman 1989:38). The teacher educator needs to help the trainees to realize how their behaviors and actions affect pupil participation or lack of it. This realization can be initiated through the way theory of education is related to practice. "By asking the student to reflect on his/her practice by asking questions, by making observations in a detached way, by sharing personal teaching experience, the collaborator endeavors to start the teacher on a process of reflection, critique and refinement of the teacher's classroom practice. (Freeman 1989:40) The main role of the teacher educator should be to trigger change through the trainee's awareness rather than to be prescriptive. The studentteacher needs to generate his/her own solutions through development.

On the other hand Freeman (1989) agrees with Richards that the teacher educator has to train the student teacher. (Freeman 1989:39) states that training "is based on the assumption that through mastery of discrete aspects of skills and knowledge, teachers will improve their effectiveness in the classroom" Although some aspects of effective teaching can be operationalized and presented to teachers in training as techniques to be mastered, there is more to teacher preparation than skills training. Richards (1987) argues the student teacher must adopt the role of an autonomous learner and researcher in addition to that of apprentice.

\section{Statement of the problem}

The expansion of education in Zimbabwe had positive as well as negative effects on Teacher Education and education in general. Immediately after independence experienced teacher educators relocated to the United Kingdom and Australia and colleges were manned by personnel without much Teacher Education experience. Larger numbers of students were enrolled and the teacher educators were inundated with a lot of work. The study sought to examine to what extent teacher educators in Zimbabwe are developing reflective skills in their student teachers.

\section{Research questions}

To what extent are the teacher educators competent in developing reflective skills in the student teachers?

Are the lecturers reflective in their own approach to teaching?

To what extent is the use of micro and peer teaching effective in developing reflective skills in student teachers? 


\section{Objectives}

To investigate how reflective student teachers are as a consequence of their training.

To discuss how teacher educators integrate theory and practice as a means of developing reflective practice.

To demonstrate how micro and peer teaching strategies are developing reflective skills in student teachers.

\section{Methodologies}

A case study of one of the colleges where the "A" level teacher education course was developed purposely sampled where final year students were randomly chosen for the study. The questionnaire administered to students and teacher educators included questions on the relationship between theory and practice in Zimbabwean teacher education colleges. The student teachers were asked to evaluate the main teaching and learning strategies used in colleges. They had to determine how far the teaching strategies influence how they in schools. Both teacher educators and student teachers were asked to summarize any problems related to teaching practice they faced. Precautions were taken in order to ensure that questions asked on student questionnaires were repeated in lecturers' questionnaires in order to triangulate the responses. An analysis of the teaching practice assessment /supervision instrument was performed in order to confirm or deny the responses of both the lecturer and student teachers. The data was subjected to content analysis through the use of SPSS. Data collection included individual interviews, focus group discussions, observations of the visual data workshop with students, and analysis of written assignments. Visits to the schools where student teachers practiced were also done. The data was collected over the period of two semesters using a purposeful sample of 60 students and 20 teacher educators. Triangulation which is a means of bringing different kind of evidence into some relationship with each other so as to compare and contrast the data collected from the teacher educators, students and supervision forms was done.

\section{Results: Relationship between Theory and Practice}

The respondents were asked to react to statements concerned with the relationship between theory and practice of the courses offered in Zimbabwean colleges.

Table 1 relationship between theories and practice( 20 respondents) Statements Lecturer frequency response

\begin{tabular}{|l|l|l|l|l|l|l|l|l|l|}
\hline & SA & $\%$ & A & $\%$ & Dis & $\%$ & DK & $\%$ & NR \\
\hline $\begin{array}{l}\text { Educational principles more } \\
\text { important than main subject }\end{array}$ & 2 & 10 & 1 & 5 & 16 & 80 & - & - & 1 \\
\hline $\begin{array}{l}\text { Subject content is given prominence } \\
\text { than Theory of education }\end{array}$ & - & - & 9 & 45 & 10 & 50 & 1 & 5 & 0 \\
\hline $\begin{array}{l}\text { Theory of education is linked to } \\
\text { subject methods }\end{array}$ & 6 & 30 & 8 & 40 & 5 & 25 & 1 & 5 & 0 \\
\hline $\begin{array}{l}\text { Subject knowledge is emphasized } \\
\text { than subject methods }\end{array}$ & 6 & 30 & 7 & 35 & 7 & 35 & - & - & 0 \\
\hline $\begin{array}{l}\text { Theory is not linked to subject } \\
\text { methods }\end{array}$ & 3 & 15 & 1 & 5 & 16 & 80 & - & - & 0 \\
\hline
\end{tabular}

Key SA- Strongly Agree, A -Agree, Dis- Disagree, DK - Don’t know, NR- No response

Table 2 Relationship between theories and Practice (60 respondents) Statements Student frequency response

\begin{tabular}{|c|c|c|c|c|c|c|c|c|c|}
\hline & SA & $\%$ & $\mathbf{A}$ & $\%$ & DA & $\%$ & DK & $\%$ & NR \\
\hline $\begin{array}{l}\text { Educational principles } \\
\text { important than main subject }\end{array}$ & 5 & 8 & 25 & 42 & 28 & 47 & - & - & 2 \\
\hline $\begin{array}{l}\text { Subject content is given prominence } \\
\text { than Theory of education }\end{array}$ & 6 & 10 & 16 & 27 & 37 & 62 & 1 & 2 & $\mathbf{0}$ \\
\hline $\begin{array}{l}\text { Theory of education is linked to } \\
\text { subject methods }\end{array}$ & 16 & 27 & 27 & 45 & 16 & 27 & 1 & 2 & 0 \\
\hline $\begin{array}{l}\text { Subject knowledge is emphasized } \\
\text { than subject methods }\end{array}$ & 14 & 23 & 22 & 37 & 22 & 37 & - & - & 2 \\
\hline $\begin{array}{l}\text { Theory is not linked to subject } \\
\text { methods }\end{array}$ & 11 & 18 & 10 & 16 & 38 & 63 & - & - & 1 \\
\hline
\end{tabular}

Key SA- Strongly Agree, A -Agree, Dis- Disagree, DK - Don’t know, NR- No response

The lecturers or teacher educators and students' responses to the way education theories relates to subject content is summarized in Tables 1 and 2. Whilst $80 \%$ of the lecturers do not believe that educational theory is 
more important than the main subject content, 50\% of the students responses showed that they felt that educational theory is given greater prominence than subject content.Some $47 \%$ of the students agreed with lecturers that education theory is not more important than subject content. An analysis of the college time table was done to check the hours allocated for the different subjects. Educational theory is allocated 72 hours per term whilst subject content is allocated 54 hours per term. If one compares allocation of time one is tempted to assume that theory of education is given more time as opposed to main subject content. However it should be noted that when students are enrolled at Hillside teachers' college it is assumed that the student passed the content at " $\mathrm{A}$ " level. The curriculum designers assume thatstudents have a sound background of their content since they passed "A 'level.

\subsection{Integration of the courses taught}

The question of whether theory was linked with subject methods was perceived similarly by both teacher educators and students. Tables 1 and 2 show that whilst $30 \%$ and $27 \%$ respectively of the respondents strongly agreed that there was integration $40 \%$ and $50 \%$ respectively agreed. However $15 \%$ teacher educators and $17 \%$ students argued that there was no integration. The data shows that there is integration of education and teaching of main subjects. It is surprising however that whilst the students complain that time allocated to methods is inadequate, they argue that education is integrated with the methods course. Perhaps the lecturers in the education department do show in general terms the relationship of the theory and methods.

\subsection{Relationship between subject content and methods.}

In tables 1 and 2 lecturers and student teachers agreed that content is emphasized than methods. About $65 \%$ lecturers and $70 \%$ student teachers argued that they agreed with the view that content is given priority than methods courses. When one analyses the time allocated to methods courses, there is a general trend of lecturers spending more time teaching content rather than methods of teaching the main subject.Part of the reason why lecturers are comfortable teaching content is because most lecturers use the content they learnt when they were at University to teach students the content of the main subject. The majority of lecturers are not trained at methods of teaching specific subjects. The majority of the qualifications they hold in professional studies is Graduate Certificate in education which is a basic qualification. There is therefore need for most lecturers in teachers college to study methods of teaching their various subjects so that they are competent in training and developing adequate skills of teaching various subjects.

Tables 3Teaching methods used at College (20 respondents)

\section{Methods Frequency of Lecturers' responses}

\begin{tabular}{|c|c|c|c|c|c|c|c|c|c|}
\hline & $\mathbf{O}$ & & $\mathbf{O}$ & s & $\%$ & $\mathbf{N}$ & $\%$ & & \\
\hline Lecture & 8 & 40 & 10 & 50 & 2 & 10 & - & - & 0 \\
\hline Group discussion & 4 & 20 & 8 & 40 & 7 & 35 & 1 & 5 & 0 \\
\hline Pair Work & 3 & 15 & 5 & 25 & 9 & 45 & 3 & 15 & 0 \\
\hline Group research & 2 & 10 & 1 & 5 & 10 & 50 & 7 & 35 & 0 \\
\hline Games & - & - & 1 & 5 & 6 & 30 & 13 & 65 & 0 \\
\hline Simulation & - & - & 2 & 10 & 8 & 40 & 10 & 50 & 0 \\
\hline Brainstorming & 1 & 5 & 6 & 30 & 11 & 55 & 2 & 10 & 0 \\
\hline Individual tutorial & 3 & 15 & 3 & 15 & 9 & 45 & 5 & 25 & 0 \\
\hline Drama & - & - & 3 & 15 & 5 & 25 & 12 & 60 & 0 \\
\hline Debates & - & - & 2 & 10 & 9 & 45 & 9 & 45 & 0 \\
\hline Cartoons & - & - & 2 & 10 & 5 & 25 & 12 & 60 & 1 \\
\hline & & & & & & & & & \\
\hline
\end{tabular}

Key: vo- very often $o-$ often $s$ - sometimes $n-$ never $n \mathbf{r}$ no response

Table 4 Teaching methods used at college

Methods Frequency of student' responses (60 respondents)

\begin{tabular}{|c|c|c|c|c|c|c|c|c|c|}
\multicolumn{1}{c}{ VO } & \multicolumn{1}{c}{$\mathbf{~ O}$} & \multicolumn{2}{c}{ \% } & \multicolumn{2}{c}{ \% } & \multicolumn{2}{c|}{ N } & \multicolumn{1}{c|}{ NR } \\
\hline Lecture & 42 & 70 & 11 & 18 & 6 & 10 & - & - & 1 \\
\hline Group discussion & 7 & 12 & 14 & 23 & 30 & 50 & 9 & 15 & 0 \\
\hline Pair Work & 9 & 15 & 5 & 8 & 24 & 40 & 22 & 37 & 0 \\
\hline Group research & 3 & 5 & 3 & 5 & 34 & 57 & 20 & 33 & 0 \\
\hline Games & - & - & - & - & 5 & 8 & 55 & 92 & 0 \\
\hline
\end{tabular}


Developing reflective practitioners in Zimbabwe Teachers' Colleges

\begin{tabular}{|c|c|c|c|c|c|c|c|c|c|}
\hline Simulation & 8 & 13 & 5 & 8 & 4 & 7 & 42 & 70 & 1 \\
\hline Brainstorming & 5 & 8 & 3 & 5 & 24 & 40 & 28 & 47 & 0 \\
\hline Individual tutorial & 2 & 3 & 4 & 7 & 17 & 28 & 37 & 62 & 0 \\
\hline Drama & 1 & 2 & 3 & 5 & 9 & 15 & 46 & 77 & 1 \\
\hline Debates & 2 & 3 & 3 & 5 & 11 & 18 & 44 & 73 & 0 \\
\hline Cartoons & 1 & 2 & 1 & 2 & 8 & 13 & 48 & 80 & 2 \\
\hline Demonstration & 6 & 10 & 5 & 8 & 27 & 45 & 20 & 33 & 2 \\
\hline
\end{tabular}

KEY: VO- Very often O - Often S - Sometimes N - Never N R No response

Table 3 and 4 indicates the different teaching methods that are used at Hillside Teachers' college. Each respondent was asked to state the frequency that each of the methods was used. The assumption was that after identifying the methods that are frequently used, then one could analyze which methods could help the students to reflect on their work and as a result encourage the development of reflective skills. Whilst $90 \%$ of the lecturers stated that they used lecture method in teaching the students $88 \%$ of the student respondents confirmed. Some of the reasons for the major use of lectures is due to large enrolments. Education and Professional study lectures are performed in mass lecture rooms where the lecturers will be dealing with 500 students. The main subject lecturers can possible use other interactive approaches. Group discussion are common when lecturers meet the students in smaller groups. Language teachers and their students affirmed thatpair work, simulation, brainstorming, drama and debates are frequently used when discussing novels and language issues. Students and lecturers in the humanities confirmed that these individualized teaching approaches were used.

Table 5 Methods used by student teachers on teaching practice (60 respondents) Methods Frequency of student responses

\begin{tabular}{|c|c|c|c|c|c|c|c|c|c|}
\hline \multicolumn{2}{|c|}{ VO } & $\%$ & \multicolumn{2}{|c|}{$0 \%$} & \multicolumn{2}{|c|}{$\mathrm{S} \quad \%$} & $\mathbf{N}$ & \multicolumn{2}{|c|}{ NR } \\
\hline Lecture & 16 & 27 & 6 & 10 & 31 & 52 & 5 & 8 & 2 \\
\hline Group discussion & 26 & 43 & 22 & 37 & 10 & 16 & - & - & 2 \\
\hline Pair work & 16 & 27 & 25 & 42 & 17 & 28 & - & - & 2 \\
\hline Group research & 3 & 5 & 8 & 13 & 25 & 42 & 24 & 40 & 0 \\
\hline Games & 7 & 12 & 8 & 13 & 21 & 35 & 23 & 38 & 1 \\
\hline Learners experiment & 5 & 8 & 5 & 8 & 19 & 32 & 31 & 52 & 0 \\
\hline Brainstorming & 6 & 10 & 10 & 16 & 21 & 35 & 21 & 35 & 2 \\
\hline Individual tutorial & 13 & 22 & 15 & 25 & 24 & 40 & 5 & 8 & 3 \\
\hline Drama & 5 & 8 & 5 & 8 & 20 & 33 & 27 & 45 & 3 \\
\hline Debates & - & - & 15 & 25 & 5 & 8 & 36 & 60 & 4 \\
\hline Cartoons \& drawing & 1 & 2 & 5 & 8 & 16 & 27 & 33 & 55 & 5 \\
\hline Demonstration & 18 & 30 & 18 & 30 & 19 & 32 & 2 & 3 & 3 \\
\hline & & & & & & & & & \\
\hline & & & & & & & & & \\
\hline
\end{tabular}

\section{Key V O - Very Often O - Often, S - Sometimes N - Never N R - No Response}

Table 5 shows the teaching method mainly used by the student teachers when on teaching practice. $37 \%$ student teachers stated that they used the lecture method. One could argue that the students might be influenced by the way they are taught at college. Since $88 \%$ of students and $90 \%$ of lecturers stated that lecture method is the most prevalent method of use at college, it's only fitting for the student teachers to model how they were taught. Pair work $(69 \%)$ and group discussion $(80 \%)$ are the other method used by students in schools. The students who teach languages and humanities use these method more often that the rest of the other subject areas. Teachers in the languages give a lot of pair work and group discussion. It is easier for most students to argue in their mother tongue when discussing various topics of interests. Brainstorming is a method used by most students when they are introducing a new topic. It was clear from the focus group discussion that that area of methodology requires some staff development on the part of the lecturers. If lecturers use these strategies of teaching, the students will model what their lecturers do when they are practicing teaching practice.

\subsection{Effectiveness of peer teaching}

Focus group discussion with student teachers showed that the student teachers felt that they were not given an opportunity to observe experienced teachers teach. The peer teaching that takes place at college did expose the student teachers to teach, however most of the student teachers felt that the major weakness with peer teaching is that it is too artificial. One student stated "It gives the teacher a false class climate." The evidence 
discussed thus far shows that courses organized at college do not adequately prepare the student teacher with the skills to be effective reflective practitioners. There is need for the courses that student learn at college to be organized in such a way that theory and practice should help the student teacher to make decisions related to practical activities that lead to pupil learning.

After the analysis of the student teacher supervision forms it was clear that there are the students who use the mother tongue Shona and Ndebele teach their subject effectively using innovative approaches to learning. One observation that came through the focus group discussion was that teacher educators who use innovative approaches to their teaching tend to influence their student teachers to do the same in their classrooms. Some of the problems that student teachers face in schools has a bearing on their failure to develop reflective skills. The deployment of student teachers to schools without textbooks, poor classroom facilities, where pupils are sent to school on empty stomachs makes difficulty for students to be creative. Instead of student teacher being creative and develop their teaching skills, they are more worried in developing survival skills for the four months that they are deployed as student teachers. If the teacher educator is to influence the student teacher to be reflective, creative and innovative, it is critical for the teacher educator to teach by example. During the learning process at college there is need for the lecturers to use small group discussion, demonstration, simulations, games and brainstorming. Exposure to these teaching strategies will motivate the student teachers to expose their pupils to the creative strategies used by teacher educator.

The development of reflective skills will only take place if a lecturer is skilled in stimulating the student teachers to reflect and critically evaluate on their teaching. Through focus group discussion, some student teachers complained that some lecturer tend to criticize their teaching approaches. One student argued that" Some of the lecturers vehemently accuse student teachers of lowering the Standard of education in the country, then go on to give their suggestions rudely." In order to encourage development in students there is need to provide the student teachers with a chance to interact regarding their practice. The teacher educator should give the student with opportunities to suggest alternative ways of teaching their subject. Lecturers should develop skills of questioning that will force the student to think of alternative teaching of his /her lessons. Such a strategy empowers the student to have several techniques to teach his /her subject.

It can be argued that giving a student teacher the chance to watch his/her colleague teach allows them to see teaching from a different perspective. One of the student teachers stated in a focus group discussion, "I used to look at teaching as a delivery of content. Through observing others teach I have learnt that what the teacher does and the activities he organizes will affect the effectiveness of the lesson." Judging from these comments from the student teacher, both the lecturer and student teachers it is clear that peer teaching plays a vital in developing the students' reflective skills.

\subsection{Interpreting the effectiveness of supervision}

During focus group discussion both lecturers and student teachers concurred that teaching practice supervision is not provided enough time for discussion and development. Although some lecturers perceived the supervision as a platform for correcting students' errors, and developing their teaching skills, students felt the strategies used by some teacher educators were not appropriate. Some students were of the opinion that they were deployed to school that are so remote that it is pointless to ask for help in a school manned by temporal teachers. They argued that at times they had to rely on their initiative even when faced with situations where they desperately needed help and professional advice. The poor facilities in some schools and lack of resources such as textbooks do not lay a good foundation for students to effectively learn how to teach. Since the student teachers are beginners there is need for them to be sent to school where there are adequate resources and experienced teachers who can provide craft knowledge. On the other hand some scholars might argue that student teachers should be exposed to different environments of where they will work. However it is important for the government to provide adequate resources such as transport, manpower, to adequately supervise the students.

One of the major challenges facing the training and development of student teachers is the failure to remunerate the mentors who are supposed to train and mentor the students during the period when they are attached to the school for four months. The experienced teachers who are identified by the school head do not see the immediate benefits of helping the student teacher because they are not given an allowance for their contribution in training and development of the student teacher. The only long term benefit that a teacher who is engaged in mentoring is that of self- development and the improvement of their Curricula vitae. For the future if mentoring is to be taken seriously there is need for teachers colleges to have a budget to pay the mentors.

The teacher educators need to develop strategies that stimulate critical thinking and reflective practice during the visits they make as they supervise the student teachers. During focus group discussion, some students intimated that lecturers should avoid being prescriptive when supervising lessons. One of the students stated that, "For the three times that I was supervised by the same lecturer, he did not have time to discuss the lesson with me. I was only grateful that I was awarded a passing grade." Although most students admitted that they 
were given useful comments by their lecturers, during the supervision process, it is evident from the students' comments that there are some lecturers who do not behave professionally. Lecturers and students should develop a friendly professional relationship so that the students feel free to consult the teacher educator at any time that he/she requires help. One could argue that poor student lecturer relationship inhibits the development of reflective skills.

The supervision process should be structured in such a way that the student teacher and teacher educator collaborate or engage in a process of interaction in order to generate change in the student teacher. This process can be developed provided the teacher educator is prepared to listen to the student teacher and spends time discussing issues related to classroom practice.

One other complaint which was stated by student teachers during focus group discussions was that most lecturers do not give them a chance to explain the reasons for using certain teaching strategies. If the lecturer is opposed to the method used by the student he/she is given a failing grade. Some of the comments written in the supervision forms written by lecturers confirm the complaint of the student teachers. Supervision is meant to mould student teachers into being professional teachers. The underlying belief behind such a belief is that the students are novice, therefore they should take orders from the experts the teacher educators. Such an attitude is not helpful in developing professional teachers.

One other challenge facing teacher education in Zimbabwe is our failure to distinguish between supervision and assessment when helping the student teacher during teaching practice. Lecturers are always in a hurry to assess as many students as possible. As one of the lecturers summarized this challenge, "The main objective of the assessment is to fulfill the requirements of the University of Zimbabwe who are the certifying University." It is unfortunate that such a practice does not take into consideration the skills that the student teacher acquires in the process let alone the development of reflective skills. If the Zimbabwean teacher education program is to be developed and transformed into programs that produce skillful reflective practitioners, then the structure of the teaching practice need to be revisited as a matter of urgency.

The teacher educator as a collaborator should develop skills of triggering the process of reflection. $\mathrm{He} / \mathrm{she}$ should develop skills of asking the appropriate questions and making the right comments that will trigger the process of reflection. The teacher educators' job is to encourage the student teacher to generate his /her own solutions to the problems of the classroom. The student teacher on the other hand can contribute to the development of his/her teaching skills. The student teacher can start by identifying the issue under reflection. e.g. The role of teacher talk in pupil learning. When the teacher organizes tasks the objective of investigating e.g. Does teacher talk affect pupil learning? In what way can teacher talk be used effectively in order to maximize pupil learning?

The student teacher will plan his /her lessons with the objective of investigating the role of the teacher talk in the learning process. When the teacher organizes tasks for the pupils he questions himself and herself whether there is need to explain the task before the pupils tackle the task. Are the tasks self-explanatory? Will the slow learners understand the tasks? The student teacher can audio tape or video tape the lesson so that after the lesson he/she can review and analyze the role of teacher talk in helping the pupils to learn. Having analyzed the lesson the student teacher can plan the next lesson taking into consideration the findings he/she has learnt from the previous lessons.

\subsection{Summary of findings}

Regardless of the limitations which have been cited above a number of interesting findings were made. The study has shown that although educational theory is related to practice, there is need for colleges to improve their methods courses. 'It has been argued that too much time is spent on teaching content of main subject at the expense of methods courses. Although peer teaching lays the foundation for the development of reflective teaching, lecturers need to take time in guiding student teachers after supervision so that students have got time to reflect on their performance. Micro teaching could be reorganized in such a way that it helps the students to reflect on their practice and take measures to improve teaching approaches. Almost all students stated that they were not given the chance to observe experienced teachers teach. Failure to provide some remuneration or allowance to mentors has a negative bearing on the role played by these teachers in developing student teacher skills.

There is need to reorganize the teaching practice model in order to differentiate between supervision and assessment. Lecturers do not have adequate time to discuss the lesson with the student teachers because they are always in a hurry to fulfill the requirements of the certifying University of Zimbabwe requirements. Failure to interact effectively after the lesson is a major weakness of the supervision process, a key element of the development of reflective skills. Finally a number of lecturers require training on the strategies of developing reflective skills. 


\section{The Way Forward \\ 9.1 Proposal to integrate theory and Practice}

One of the observations from the study was that it is important to integrate theory and practice. Most student teachers were of the opinion that the educational theory was integrated with practice but they argued that the course does not expose them adequately to the methods of teaching in the classroom. It is important for courses to be structured in such a way that there is openness of procedure. Every aspect of training needs to be planned openly so that lecturers in different departments know what is being done in the other departments. Coordination in college will ensure that lecturers will complement one another.

Lecturers need to agree as a team on the rationale behind the structure of their courses. The design of a task based syllabus in the different college departments will ensure that students learn through interaction and the tasks can be structured in such a way that they force the student to reflect on his /her past learning experience, on the role of educational theory and the function of professional studies to what the student does in class.

\subsection{Proposal of transforming the teaching strategies.}

There is need for the College to plan for staff development programs where college lecturers discuss how they can transform their teaching strategies. The following tasks could be designed so that they become the basis for brainstorming:

(i) How to develop task based activities to be used in a lecture

(ii) The role of brainstorming in the learning process

(iii) Organizing group activities in large classes

(iv) The selection of learning material

(v) Drama as a teaching tool

(vi) Role of demonstration in studying the humanities

The use of these staff development sessions will provide ideas to lecturers. Exposure to some of these creative teaching strategies will encourage the student teachers to model what their lecturers were using in their classrooms. It is unlikely that students will develop much skill or understanding of the interactive technique of teaching when they get to schools, if they are taught mainly through didactic lectures.

\subsection{Restructuring the supervision process}

There is need to differentiate between supervision and assessment. At college when students are exposed to peer teaching and micro teaching, there is need for lecturers to demonstrate how supervision is done. Focus should not be on awarding a grade but to develop teaching skills. Students should then be deployed to schools that are close to the college so that a process of supervision is developed. A supervision instrument should be designed whose focus is not to award a grade but to develop reflective skills. The college curriculum can be structured in such a way that once a week during year two, students have a practical teaching period where they are expected to teach pupils in a school close to college. The students can be organized in small groups to visit the school under the supervision of the tutor as a means of studying the school context and the requirements of the curriculum.

\subsection{Reorganizing the mentorship programme}

The present teacher education programme was designed to meet the need of an expanding education system where lots of schools were being built and there was need for teachers in large numbers. Student teachers were supposed to provide a stop gap measure in providing manpower at a time when schools were expanding rapidly. Thirty years after independence Zimbabwe needs to focus on quality. Instead of producing mediocre graduates, there is need for government to be concerned with the final product. Colleges should identify experienced teachers who will be given an allowance for their services. The mentor will offer to the student at his/her request the help that is required. The mentor can provide personal support for the student teacher. Student teachers have problems of judging the length of time required to do certain activities. The mentor can also provide support for curriculum development. The mentor can help the student teacher in reflecting on his/her practice. The student teacher will learn from the craft knowledge of the experienced teacher if there is time for reflective conversation. McIntyre and Hagger (1993) argued that it is crucial for the ideas of the student teacher to be examined critically because most of the ideas of the student teacher can be narrow, prejudiced and incoherent. Advising the student teacher s during the supervision process helps them not only to become better teachers but to develop skills, understand the learning process, and the development of reflective skills. 


\section{References}

[1]. Barnes, D. Britton J.and Torbe M. (1990) Language, the Learner and the School( $4^{\text {th }}$ edition PortsmouthHeinemann

[2]. Buchanan, M. (1983) Justification in Teacher thinking: an analysis of interview data Research series no 124 East LansingMichiganState university.

[3]. Chivore, B.R.S. (1986) Teacher Education in Post independent Zimbabwe: problems and Solutions. Journal of Education for Teaching vol1 2/3 205-232

[4]. Freeman D.(1990) Intervening in practice teaching in Richards and D. Nunan (ed) Second Language Teacher Education. Cambridge: CambridgeUniversity Press. 103-117.

[5]. Gattegno, C. (1987) The Science Education New York Education Solutions

[6]. McPhie, P. (1978) A Teacher Education Dilemma : practical application theory. Journal of Teacher Education.vol 29/ 1978, 53-56

[7]. Morrison, J. W.(1988) Consultancy to advise on program to enhance communication skills in teacher education. ODA financial consultancy for the Ministry of Education and Culture. Harare :Zimbabwe

[8]. Richards, J.C.(1987) The Dilemma of Teacher Education in Tesol Quarterly vol21/2

[9]. Richert, A.E. (1992) The content of student Teacher reflection within different structures for facilitating the reflective process in Russell and H. Munby (eds) Teachers and Teaching

[10]. Rudduck, J. (1992) Practitioner research and programs of initial teacher training IN T. Russell and H. Munby (eds) Teacher and teaching from the classroom to reflection London: Falmer press 156-169

[11]. Sanders J. J. and McPeck J.E. (1976) Theory into Practice or vice versa The Journal of Educational Thought vol. 101976188 - 193

[12]. Stones E. (1983) Perspectives in Pedagogy. Journal of Education for teachingvol .9/1983 68-76

[13]. Stones E. (1987) Student Teaching in M.J. Dunkin (ed) The international Encyclopedia of Teaching Teacher Education Oxford: Pergamon press

[14]. Schon D. A. (1987) Educating the reflective practitioner, London: Jossey Bass Publishers

[15]. Wubbels, T. and Korthagen F.A.J. (1990) The effects of a pre service Teacher Education program for the preparation of Reflective teachers. Journal of Education for Teaching vol. 16/1 /1990 29-43

[16]. Van Manen (1977) Linking ways of knowing with ways of being practical Curriculum Inquiry Vol 5205 -228

[17]. Verloop, N. (1989) Interactive cognitions of student teachers

[18]. Netherlands Arnhem national institute for Educational Measurement

[19]. Wallace,J.M. (1991) Training Foreign language Teachers (A reflective Approach New York: Cambridge University press

[20]. ZIMSTAT (2012) Zimbabwe Statistical

[21]. Zeichner K.M. (1981) Reflective teaching and field based experience in Teacher EducationInterchange vol.12 no $422-34$

\section{Appendix 1}

The University of Leeds

\section{Questionnaire for lecturers}

\section{School of Education}

Iam doing a research on developing reflective teaching skills in the classroom for student teachers. The information sought from you is intended to highlight how Teachers' Colleges in Zimbabwe develops teaching skills in their students.All responses will be treated with the strictest confidence.

\section{TEACHING STRATEGIES AT COLLEGE}

1. What subject do you teach?

(Pick the appropriate response. Key 1. I don't know, 2. Strongly disagree. 3. Disagree 4. Agree 5. Strongly agree

2. How true are following statements with reference to what happens at your college?

(a) Basic educational principles are more important than subject knowledge.

(b) Knowledge of subject content is given more emphasis than theory of education

(C) Theoryof education is clearly linked to the subject methodology

(d) Subject content is emphasized than subject methodology

(e) Theory of education is not linked to subject methodology

3. How frequently are the following methods used in your classes?

Key: 1. Never, 2.Sometimes, 3. often, 4. Very often
(a) Lecture
(b) Group discussion
(c) Pair work
(d) group project
(e) Games
(f) Simulation
(g) brainstorming
(h) tutorial
(i) Drama
(j) debates
(k) Cartoons

Any other

\section{STUDENT SUPERVISION}

4. Do you do any of the following activities at your college?

(a) Micro teaching

$$
\text { Yes }
$$

No

(b) Peer teaching

Yes No 
(c) Observing experienced teachers teach. Yes No

(a)

What

are

benefits

of

micro

teaching?

5 (b) State the benefits and disadvantages of peer teaching?

5 (c) What can student teachers learn from observing experienced teachers?

6 (a) to what extent is the supervision process helpful in developing student teacher teaching skills?

Key Not helpful, Not very helpful, helpful, very helpful,

6

(b)

Please

give

reasons

7 What do lecturers do when you make errors?

teachers.

8. State areas that you think need revisiting in order to improve the teaching skills of student Thank you

Appendix 2

The University of Leeds

Questionnaire for Student teachers

School of Education

Iam doing a research on developing teaching skills in the classroom for student teachers .The information sought from you is intended to highlight how Teachers' Colleges in Zimbabwe develops teaching skills in their students All responses will be treated with the strictest confidence .

TEACHING STRATEGIES AT COLLEGE

1. What main subjects are you studying at College? and

\section{(Pick the appropriate response}

Key 1. I don't know, 2. Strongly disagree. 3. Disagree 4. Agree 5. Strongly agree

2. How true are following statements with reference to how you course is organized at College?

(a) Basic educational principles are more important than subject knowledge.

(b) Knowledge of subject content is given more emphasis than theory of education

(C) Theoryof education is clearly linked to the subject methodology

(d) Subject content is emphasized than subject methodology

(e) Theory of education is not linked to subject methodology

3. How frequently are the following methods used in your main subject at College?

Key: 1. Never, 2. sometimes, 3. often, 4. Very often
(a) Lecture
(b) Group discussion
(c) Pair work
(d) group project
(e) Games
(f) Simulation
(g) brainstorming ( h) tutorial
(i) Drama
(j) debates
(k) Cartoons
Any other

\section{STUDENT SUPERVISION}

4. When you were doing teaching practice how frequently did you use the following methods in your classes? 


\section{Key: 1. Never, 2. Sometimes, 3. Often, 4. Very Often}
(a) Lecture
(b) Group discussion
(c) Pair work
(d) group project
(e) Games
(f) Simulation
(i) Drama
(j) debates
(g) brainstorming
(h) tutorial
(k) Cartoons

Any other

\section{STUDENT SUPERVISION}

5. Do you do any of the following activities at your college?
(a) Micro teaching
Yes
No
(b) Peer teaching
Yes
No
(c) Observing experienced teachers teach. Yes
No
6 (a) What are benefits of micro teaching?

6(b) State the benefits and disadvantages of peer teaching?

6 (c) What can student teachers learn from observing experienced teachers?

7 (a) to what extent is the supervision process helpful in developing student teacher teaching skills? (Please pick the most appropriate answer)

Key: Not helpful, Not very helpful, helpful, very helpful,

7

(b)

Please

give

reasons

8. What do lecturers do when you make errors during teaching practice?

9. Summarize any problems faced on teaching practice related to classroom practice

$\overline{\text { Thank you }}$ 